\title{
THE ENGLISH TEACHERS' MASTERY IN TOEFL PREDICTION
}

\author{
Nida Mufidah \\ IAIN Antasari Banjarmasin \\ nida_mufidah@yahoo.com
}

\begin{abstract}
Assessment is often considered as the most important part in instruction. The way of learners taught and the activity carried out in the classroom are greatly influenced by assessment, and the success of a learning program is commonly determined by the result of assessment. This research focuses on the TOEFL test giving the teachers opportunity to prove that they can communicate ideas effectively by simulating classroom and teacher life comunication. This research is then conducted to find out the English teachers' mastery in TOEFL Prediction in listening comprehension, structure and written expression, and reading comprehension at Junior and Senior High Schools in Kotabaru Regency, South Kalimantan. The research form is a field research by using written test, observation, interview, and documentary technique in collecting data. The subjects of this research were 16 English teachers of Junior and Senior High Schools in Kotabaru Regency, South Kalimantan. The result shows that the teachers' mastery of TOEFL Prediction in listening comprehension, structure and written expression, and reading comprehension is classified into good category with the mean score 423.06. It recommends English teachers in Kotabaru to apply some different strategies in teaching listening comprehension, structure and written expression, and reading comprehension of each meeting to get high motivation and interest for both teachers and students. Teachers should develop their professions joining some trainings related to English instruction, encourage their students to practice skimming and scanning skill and identify the major poins of the passage, and use the context for vocabulary mastery by listening comprehension and for structure and written expression as well in the teaching and learning through games and fun activities.
\end{abstract}

Keywords: assessment, English teacher, mastery, TOEFL Prediction

Today we are all still deeply affected by test and examination especially high stakes of standardized tests. Almost century, schools, universities, business, and government have looked to standardized measures for economical, reliable and valid assessment of those who would enter, continue in, or exit their institutions. Proponents of these large scale instruments make strong claims for their usefulness when great numbers of people must be measured quickly and effectively.
Test of English as a Foreign Language (TOEFL) is probably the most often used Examination in the admission process of foreign students to college and university in the United States (Pyle \& Munoz, 1985:4). TOEFL examines someone's abilities in mastering English; the abilities are Listening Comprehension, Structure and Written Expression, Reading Comprehension and Writing. This test evaluates the potential success of an individual to use and understand standard American English at a college level. 
The language used in the test reflects real-life English language usage in university lecturers, classes, and laboratories. It is the same language professors' use when they discuss coursework or concepts with students. It is the language students' use in study group and everyday university situations, such as buying books at the bookstore, the reading passages from real textbooks and course materials (TOEFL Tips, n.d.:4).

People take TOEFL test for many reasons; for example someone who wants to study abroad; where TOEFL test is a main requirement for non-native applicants at many US and other English-speaking colleges and universities. Another reason is because someone who wants to continue his or her study to get Master and Doctor Degree program at some universities in Indonesia where TOEFL is a main requirement. The TOEFL test is taken by someone who wants to take short course program held by an overseas institution, organization or Foundation in some certain fields. Someone who wants to occupy a higher position in government institution or to hold an important position in a private enterprise or company also takes the TOEFL test for a promotion in one's career.

The TOEFL test measures how well students use English, not just their knowledge of the language. Because it is a valid and reliable test with unbiased, objective scoring, the TOEFL test confirms that a student has the English language skills necessary to succeed in an academic setting. This is why it has become the most popular and accessible English language test in the world. It has been administrated more than 20 million times since 1994, and at more than 6000 colleges, universities, and agencies in 110 countries where are accepted TOEFL scores. This means that students have the flexibility to use their TOEFL test score worldwide (TOEFL Tips, n.d.:4).

It is a fact that even someone or teachers can speak English well, it does not ensure he or she has high score in TOEFL, it is different with someone who has an ability in listening comprehension, structure and written expression, reading comprehension and vocabulary, or has an ability in writing essays, usually he or she has good score in the TOEFL test. In others words, having a high score in TOEFL does not mean he or she has the ability in speaking English well. Perhaps, there is someone who just likes reading English passage or text and expressing English in writing, but he has difficulties to express English in spoken because of personality problems such as embrace, shy, low confidence, etc.

English teachers generally require to take TOEFL test for fulfillment of the requirement to obtain the master of English Education degree. They also have finished learning vocabulary and structure. Consequently, they are ready to face the TOEFL test, especially in TOEFL Prediction. English proficiency of teachers should be developed through some trainings of professional development as the basic needs for academics working in the field of education in particular. The course of TOEFL Prediction had been held in Kotabaru Regency followed by English teachers, under government of Eduacation Ministry of Kotabaru, and organized by English lecturers of IAIN Antasari Banjarmasin. At the same time, the writer implemented this small research by doing TOEFL test, review, interview, observations which were expected to remove our doubts to continue to improve English language skills for teachers, especially in achieving the standards established TOEFL score. Therefore, the writer assumes that it is very important to know the mastery of English teachers of Junior and Senior High School in TOEFL in Kotabaru Regency.

Based on the description above, the researcher can identify the problem of this research. The researcher formulates the research problem in order to be feasible. This focused on the problem as follows, "How is the English Teachers' mastery of TOEFL Prediction at Junior and Senior High School in Kotabaru Regency?" Meanwhile, based on the problem stated, the purpose of this research is to know the English Teachers' mastery 
of TOEFL Prediction (listening comprehension, structure and written expression, and reading comprehension) at Junior and Senior High Schools in Kotabaru Regency.

The result of the current research is expected to have advantages. First, it will be information, consideration, and input for educational administrators on increasing and improving educational quality as it is important in establishing conditions which enable the learners to acquire knowledge, skills, and attitude, so that the learning objectives are reached. Second, it will enrich the writer's knowledge and experience in the scientific research especially about TOEFL Prediction. Next, it is expected that the result can give useful insight for regional government of Kotabaru in the teachers' professional development. Finally, it will be information and a comparison for the next researchers who expect to do their research on the similar topic.

\section{METHOD}

The subjects of this reseach are 16 English teachers tested in Kotabaru Regency, South Kalimantan, 7 hours from Banjarmasin by car. The teachers were randomly chosen, at once as the participants of the training of English Teachers' Professional Development conducted by IAIN Antasari Banjarmasin. The researcher contacted Education Department of Kotabaru to ask them to be tested after training. The data was collected through written test, observation and interview. The teachers were asked to do a TOEFL Prediction test. TOEFL test consists of listening comprehension, structure and written expression, and reading comprehension.

After all of the data were collected and processed, the researcher analyzed the data by using descriptive qualitative. It is the tool for analysis that allows the researcher to give information on how the research was done.
This analysis helps the researcher to highlight some important conclusions from this research. The conclusion is taken by inductive method (making conclusion from specific fact to general). To know the teachers' mastery in TOEFL Prediction, the data were intepreted using the following formula:

$$
\begin{aligned}
& M=\frac{\sum x}{N} \\
& M=\text { Mean } \\
& \Sigma=\text { Accumulative (Epsilon) } \\
& x=\text { Total score } \\
& N=\text { Number of respondents }
\end{aligned}
$$

Table 1. The Category of TOEFL Achievement (Taken from Baron's TOEFL)

\begin{tabular}{ll}
\hline SCORE & CATEGORY \\
\hline $550-670$ & Advance \\
\hline $500-549$ & Intermediate \\
\hline$<500$ & Beginner \\
\hline
\end{tabular}

\section{FINDINGS AND DISCUSSION}

The research attempted to answer one problem statement of the teachers' mastery of TOEFL Prediction in listening comprehension, structure and written Expression, and reading comprehension.

\section{Description of the English Teachers' of Junior and Senior High School in Kotabaru Regency, South Kalimantan}

The researcher tested 16 English teachers of Kotabaru Regency. This following table shows their data as the subjects of TOEFL mastery in listening comprehension, structure and written expression, and reading comprehension.

The test had been performed once at SMA Negeri Serongga, Kabupaten Kotabaru. The time allotment for the test is as follows: listening (40 minutes), structure and written expression (25 minutes), and reading comprehension (55 minutes). 
Table 2. Data of English Teachers from Kotabaru, South Kalimantan

\begin{tabular}{|c|c|c|c|c|c|}
\hline No & $\begin{array}{l}\text { Teachers'Name } \\
\text { (Initial) }\end{array}$ & School & $\begin{array}{l}\text { Address in Kotabaru, } \\
\text { South Kalimantan }\end{array}$ & $\begin{array}{l}\text { Hand Phone } \\
\text { Number }\end{array}$ & $\begin{array}{l}\text { TOEFL } \\
\text { Score }\end{array}$ \\
\hline 1 & $\mathrm{AC}$ & $\begin{array}{l}\text { SMAN I } \\
\text { Kelumpang Selatan }\end{array}$ & $\begin{array}{l}\text { Jl. H. Abdullah Desa } \\
\text { Pantai33 }\end{array}$ & 087814251048 & 360 \\
\hline 2 & RD & $\begin{array}{l}\text { SMAN I } \\
\text { Sampanahan }\end{array}$ & Jl. Putri Zaleh & 081953206625 & 370 \\
\hline 3 & $\mathrm{IH}$ & $\begin{array}{l}\text { SMAN I } \\
\text { Kelumpang Hulu }\end{array}$ & $\begin{array}{l}\text { Jl. A.Agus S.50 A ,Gg } \\
\text { Fajar }\end{array}$ & 085226355908 & 533 \\
\hline 4 & SR & $\begin{array}{l}\text { SMAN I } \\
\text { Kelumpang Tengah }\end{array}$ & $\begin{array}{l}\text { Jl. Sukmaraga No.14, } \\
\text { KTBR Tengah }\end{array}$ & 081348561360 & 463 \\
\hline 5 & YW & $\begin{array}{l}\text { SMPN I } \\
\text { Kelumpang Hilir }\end{array}$ & $\begin{array}{l}\text { Jl. A.Yani km } 294 \\
\text { Tegalrijo }\end{array}$ & - & 380 \\
\hline 6 & EUD & $\begin{array}{l}\text { SMP Indocement } \\
\text { Tarjun }\end{array}$ & $\begin{array}{l}\text { KPR Blok D 11/4 } \\
\text { Tarjun }\end{array}$ & 081351819824 & 426 \\
\hline 7 & $\mathrm{AM}$ & $\begin{array}{l}\text { SMPN Pamukan } \\
\text { Barat }\end{array}$ & $\begin{array}{l}\text { Margajaya Rt. } 13 \\
\text { Pamukan Brt }\end{array}$ & 087816226816 & 453 \\
\hline 8 & PN & $\begin{array}{l}\text { SMAN I } \\
\text { Kelumpang Hilir }\end{array}$ & $\begin{array}{l}\text { Jl. Ratu Intan } \\
\text { Serongga }\end{array}$ & 085248267513 & 426 \\
\hline 9 & MW & SMPN I Hampang & $\begin{array}{l}\text { Komp. SMPN I } \\
\text { Hampang }\end{array}$ & - & 430 \\
\hline 10 & SE & $\begin{array}{l}\text { SMPN } 2 \text { Sungai } \\
\text { Durian }\end{array}$ & Sungai Durian & 087817251548 & 383 \\
\hline 11 & MY & $\begin{array}{l}\text { SMKN I Sungai } \\
\text { Durian }\end{array}$ & $\begin{array}{l}\text { Jl. Kenanga Rt.10 /14 } \\
\text { KTBR }\end{array}$ & 081348229188 & 423 \\
\hline 12 & DS & SMPN I Hampang & $\begin{array}{l}\text { Komp.SMP I } \\
\text { Hampang }\end{array}$ & 085248404676 & 383 \\
\hline 13 & MNE & $\begin{array}{l}\text { SMPN } 2 \\
\text { Kelumpang Selatan }\end{array}$ & $\begin{array}{l}\text { Desa bangkalan } \\
\text { Melayu }\end{array}$ & 081348195748 & 426 \\
\hline 14 & $\mathrm{AM}$ & $\begin{array}{l}\text { SMPN I } \\
\text { Kelumpang Barat }\end{array}$ & $\begin{array}{l}\text { Bungkukan Rt.5 } \\
\text { Kelump.Barat }\end{array}$ & 081349455445 & 416 \\
\hline 15 & $\mathrm{SH}$ & $\begin{array}{l}\text { SMPN } 2 \\
\text { Kelumpang Selatan }\end{array}$ & $\begin{array}{l}\text { Jl. H. Abdullah Ds. } \\
\text { Sukamaju }\end{array}$ & 081349670277 & 480 \\
\hline 16 & ES & $\begin{array}{l}\text { SMPN I } \\
\text { Kelumpang Hilir }\end{array}$ & $\begin{array}{l}\text { Kompl. SMPN I } \\
\text { Kelump Hilir }\end{array}$ & 085751458632 & 417 \\
\hline \multicolumn{5}{|c|}{ Total Score } & 6769 \\
\hline Mea & n Score & & & & 423.06 \\
\hline
\end{tabular}

All teachers above are the English teachers of Junior, Senior High School, and Vocational School of Kotabaru Regency, as civil servants under Department of Education Board of Kotabaru Regency, South Kalimantan. Based on interview, most of them have never joined the TOEFL Prediction yet. They were delighted to be the subjects, at once to know their each capability in TOEFL Prediction.
Kotabaru is located about 7 hours by car from Banjarmasin or 20 minutes by Plane. Kotabaru district is one of the districts in the province of South Kalimantan, Indonesia. The capital of the district is located in the city of Kotabaru. This district is one of the first districts in Kalimantan province. At the time of the Dutch East Indies was Afdeeling Sand en de Land Boemboe the capital's New Town. This district has an area of 
$9442.46 \mathrm{~km}^{2}$ and has a population of as many as 290,142 people (Indonesian Population Census 2010) with sea fishermen as much as 15,961 inhabitants. This area is a motto "Sa-ijaan" (Banjar language) which means: Semufakat, a heart and a one word yes.
Here is data about the test result in the teachers' mastery of TOEFL Prediction at Junior and Senior High Schools in Kotabaru Regency.

Table 3. The Test Score of the English Teachers' Mastery of TOEFL Prediction of Junior and Senior High School in Kotabaru

\begin{tabular}{llllll}
\hline No & $\begin{array}{l}\text { Teachers' } \\
\text { Initial Names }\end{array}$ & $\begin{array}{l}\text { Listening } \\
\text { Comprehension }\end{array}$ & $\begin{array}{l}\text { Structure and } \\
\text { Written Expression }\end{array}$ & $\begin{array}{l}\text { Reading } \\
\text { Comprehension and } \\
\text { Vocabulary }\end{array}$ & $\begin{array}{l}\text { TOEFL } \\
\text { Score }\end{array}$ \\
\hline 1 & AC & 43 & 33 & 32 & 360 \\
\hline 2 & RD & 43 & 35 & 33 & 370 \\
\hline 3 & IH & 52 & 53 & 55 & 533 \\
\hline 4 & SR & 48 & 45 & 46 & 463 \\
\hline 5 & YW & 43 & 35 & 36 & 380 \\
\hline 6 & EUD & 46 & 43 & 39 & 426 \\
\hline 7 & AM & 48 & 43 & 45 & 453 \\
\hline 8 & PN & 45 & 42 & 41 & 426 \\
\hline 9 & MW & 46 & 48 & 35 & 430 \\
\hline 10 & SE & 43 & 37 & 35 & 383 \\
\hline 11 & MY & 42 & 42 & 43 & 383 \\
\hline 12 & DS & 45 & 35 & 35 & 426 \\
\hline 13 & MNE & 43 & 42 & 43 & 416 \\
\hline 14 & AM & 44 & 41 & 46 & 417 \\
\hline 15 & SH & 49 & 50 & 37 & 6769 \\
\hline 16 & ES & 44 & 44 & & 423.06 \\
\hline Total Score & & & & \\
\hline Mean Score & & & & 403 \\
\hline
\end{tabular}

Based on the table above, it shows that the scores of mastery of TOEFL Prediction of the English teachers at Junior and Senior High Schools in Kotabaru Regency showed 533 (the highest score) and 360 (the lowest score) from the total score 6769. Actually if all learners' answers are correct, the score should be 670 . This achievement is the total score of 3 sections, namely listening comprehension, structure and written expression, and reading comprehension. In short, the mean score of TOEFL Prediction achievement is 423.06 . Those teachers have English educational background from different universities.
Table 4. The Frequency Distribution of English Teachers' Mastery on TOEFL Prediction at Junior and Senior High Schools in Kotabaru

\begin{tabular}{llllll}
\hline No & \multicolumn{2}{l}{ Interval Category } & Category & F & $\%$ \\
\hline 1. & $80-100$ & $536-670$ & Excellent & 0 & 0 \\
\hline 2. & $60-<80$ & $402-<536$ & Good & 11 & 68.77 \\
\hline 3. & $40-<60$ & $268-<402$ & Fair & 5 & 31.25 \\
\hline 4. & $20-<40$ & $134-<268$ & Poor & 0 & 0 \\
\hline 5. & $0-<20$ & $0-<134$ & Very Poor & 0 & 0 \\
\hline Total & & & & 16 & 100 \\
\hline
\end{tabular}


From the table above, it is obvious that there are 11 teachers $(68.75 \%)$ whose score are around $402-<536$ classified in the good category. There are 5 teachers (31.25\%) whose score around $268-<402$ classified in the fair category. Meanwhile, there is none teacher $(0 \%)$ whose score is around 536- 670, 134- $<268$, and $0-<134$. It means that there is no one teacher classified in the excellent, poor, and very poor category.

\section{Data Analysis}

After presenting the data, the writer analyzes all the obtained data to give some consideration on the research. Some consideration and analysis could be known that the teachers got a new experience when they got English test of TOEFL Prediction. They should use their time wisely since the TOEFL is timed test. The teachers were not sure to answer a question, actually they should guess best. Based on interview, while preparing for the test, they were not ready to take rest at night. It is suggested that before conducting the TOEFL test, the teachers should relax and go to bed early. Properly, when they wake up, they will be fresh and ready for the test.

The tables of description above tell about the process of implementation of the TOEFL test as a whole. They give insight that no matter how complex the skills are needed to master the English language. TOEFL material is the application of basic skills in English (such as listening, grammar and structure, vocabularies, reading and writing), and then for the TOEFL test should be able to understand the material already mastered the basic skills well. Most teachers expected to have achievement of a certain level of English profficiency, given the heavy grammar-translation. In general, the teachers had studied a lot of grammar, in fact, from a variety of teachers' schemata indicated; there were differences in their abilities to use this knowledge effectively. The teachers' approach dealing with grammar mainly involved explanations of language points, which some of the expatriate teachers seemed to find quite challenging and the use of test-like grammar exercises.

It was the biggest problem of the reading comprehension. Just individual words and it was just because they were words they had not learned in English. In general, the teachers in this study seemed confident when talking about preparing for the reading test, at least in terms of what they needed to teach if not how to go about doing it. This section examines a range of approaches to preparing teachers for the reading section of the TOEFL Prediction from those teachers who mostly consigned it to home work to those who felt a large proportion of class time should be dedicated to it. This section discusses what the teachers believed was being assessed, what they taught, and how they went about their teaching.

No matter whether it is listening, speaking, reading, or writing-all of these are strongly bound by time restrictions. After teachers become aware of the structure of the test, they should then focus on achieving the structural requirements within the appropriate time limits. If they cannot finish the tasks within the required period of time, then this is something that a teacher must begin to focus on giving the best chances at achieving their goal for the TOEFL examination.

Based on interview, all of the teachers believed that TOEFL assessed the ability to understand a wide range of texts, most of the teachers were highly dependent on their preparation of teaching materials, and had never learned what they knew about the TOEFL test by working their way.

After having training of TOEFL given by English lecturer of IAIN Antasari Banjarmasin, they open their mind to recognize and learn course book of TOEFL more. It is hard to determine what role the actual test plays in shaping TOEFL teaching and learning since everything is nearly mediated through the course book. The course books contain the basic information that teachers need about 
the TOEFL test (information about the overall structure of the test item and task types, texts, and tasks, and general advice about what to focus on) as well as providing answer keys. However, they generally do activity including advising to the teachers about how to teach the target skills effectively. So, it would be useful if the course books offered suggestions about how to deal with language students having been introduced to elsewhere.

Based on the findings, English proficiency of teachers should be developed through some trainings of professional development as the basic needs for academic working in the field of education in particular. From the above reviews, interviews, and observations, it is expected to remove the doubts to continue improving English language skills, especially in achieving the standards of the established TOEFL score.

\section{REFERENCES}

Brummitt-Yale, J. (n.d.). Reading Comprehension. From http://www.k12reader.com/ what-is-reading-comprehension/, Retrieved on January 15, 2014.

Matthiesen, S. (n.d.). Essential Words for the TOEFL (Test of English as a foreign Language). New York: Barron's.

Pyle, M., \& Munoz, M.E. (1985). Test of English as a Foreign Language Preparation Guide. Lincoln: Cliffs Notes. Inc.

Riyanto, S. (2007). The $1^{\text {st }}$ Student's Choice TOEFL (Test of English as a Foreign Language). Yogyakarta: Pustaka Pelajar.

Sharpe, P. (2000). Barron's How to Prepare for the TOEFL Test of English as a Foreign Language. Jakarta: Binarupa Aksara.

Stiggins, R.J. (2001). Student-involved Classroom Assessment. Ohio: Merril Prentice.

Tarigan, H.G. (1984). Membaca Sebagai Suatu keterampilan Bahasa. Bandung: Angkasa.

\section{CONCLUSION}

After conducting the research and analyzing the data, the writer would like to conclude all the findings. Teachers' mastery on TOEFL Prediction of listening comprehension, structure and written expression, and reading comprehension at English teacher of Kotabaru Regency, South Kalimantan is classified into a good category with the mean score 423.06 .

Following the findings and discussions, some suggestions are given. English teachers of Kotabaru Regency are needed to apply some various strategies in the teaching and learning English through fun and game activities. Also, the head of Education Ministry of Kotabaru Regency is expected to support the teachers to join training for improving proffesional English teachers such as course of TOEFL or IELTS in the frame work to continue master degree of English. Finally, it is suggested to find several books of the TOEFL test guide in which there are a number of tips and strategies used to master the TOEFL test.

Test of English as a Foreign Language (TOEFL), http:/ / www.mytoeflsuccess.com/ toefl-test/.

TOEFL Tips, (n.d.). How to prepare to the TOEFL $i B^{\prime \prime}$. http//TOEFL_tips. How to Prepare for the TOEFL iBT.Pdf., p.4 Retrieved on January 11, 2014.

Wikipedia, the Free Encyclopedia. Reading Comprehension. http://en.wikipedia. org/wiki/Reading Comprehension., Retrieved on December 11, 2013.

Wikipedia, the Free Encyclopedia. Reading Comprehension. http://en.wikipedia. org/ Retrieved on December 11, 2013 at 12.07 .

Wikipedia, the Free Encyclopedia. TOEFL. http:/ /en.wikipedia.org/wiki/TOEFL. Retrieved on January, 2014.

Https:/ / secure.vec.bc.ca/whatistoefl.cfm? Retrieved on February 13, 2014. 
